\title{
'Troubling' Politics of Research on Young Sexual Practices in South African Contexts
}

\author{
Tamara Shefer ${ }^{1 *}$
}

Published: March 5, 2021

\begin{abstract}
In this article, I reflect on the last few decades of research on young sexual practices in the post-apartheid context of South Africa. I am concerned here to critically interrogate this body of work and its political effects, much of it spurred on by a global industry of reproductive health and HIV that has proliferated in the context of the HIV pandemic and high rates of gender-based violence. Drawing on a postcolonial, transnational feminist lens the paper surfaces the problematic discourses that have been reproduced and reinscribed through this research and related policy and practice, foregrounding the way in which racist, classist, heteronormative and ageist discourses, which also serve to privilege global Northern, adultist and middle class, white moralities and normativities, have been bolstered. Arguing that these problematic politics of mainstream sexualities research are linked to the continued dominance of patriarchal, colonial logics of knowledge which are based on extractivism, representation and surveillance, the article concludes with some thoughts and possibilities for reimagining future scholarship on intersectional, transnational gender and sexual justice.
\end{abstract}

Keywords: young people, sexualities, South Africa, postcolonial transnational feminist critique

\section{INTRODUCTION}

This article draws on the now large body of work on sexual practices, particularly as directed at young people in the post-apartheid South African context. My primary project here is to think critically about the ideological and political impact of such research. I provide a critique of this body of work to argue how much of this body of work has served to reiterate and reinstate lines of power, authority and privilege endemic in colonialist, patriarchal scholarly traditions, while bolstering the racist, heteronormative, and other epistemological violences feminist and critical scholars had hoped to challenge. I read this research critically towards highlighting what we may learn about doing critical transnational, decolonial feminist research through an interrogation of contemporary research on young sexual practices in South Africa.

The last quarter of a century of research in South African (and arguably many global Southern) contexts speaks powerfully to transnational research, highlighting in particular the dangers and pitfalls of applying such gender research across diverse contexts in the light of continuing inequalities, at multiple levels, between different parts of the world (see also Hearn, Ratele and Shefer, 2017; Ishengoma, 2016; Shefer, Hearn and Ratele, 2015). This paper attempts to unpack the embeddedness of much of the research on young sexualities in South Africa in an epistemologically violent politics of knowledge. The article concludes by contributing some thoughts towards alternative possibilities for a critical feminist engagement, across diverse geopolitical contexts, that foregrounds a politics of reflexivity, care and relationality, drawing particular inspiration from the knowledges that emerge from the fruitful entanglements of decolonial, feminist and queer art, activism and scholarship.

This article begins by overviewing the terrain of the critique, which speaks also to a larger concern about injustices embedded in knowledge production and the university and how this has been further entrenched in contemporary neoliberal marketisation imperatives. I will draw primarily on South African experiences and contexts to employ transnational intersectional arguments about how dominant scholarship on young sexualities remains underpinned by and reproduces existing hegemonies of intersectional gender inequalities and divides which are located within colonial and patriarchal orthodoxies of scholarly epistemology, ontology and methodology. It is notable in this respect that feminist and decolonial scholarship have been engaged in a long and 
arduous project directed at dismantling hegemonic practices in higher education that continues to operate through patriarchal and colonial logics.

In South Africa, there has been an overlapping lengthy project to transform higher education which has been shaped by the hegemonies of Eurocentric traditions that are linked with centuries of settler colonisation and apartheid's system of racist, segregated, and unequal educational institutions. Recent years - following student activism spurred by the \#fallist movements - have seen an accelerated focus and a mobilisation of decolonial and intersectional emphases in addressing social justice in higher education (see for example, Gouws, 2017; Hussen, 2018; Xaba, 2017). As a result of these shifts, those involved in local feminist scholarship in global contexts have stepped up their engagement with re-thinking and re-interpreting normative practices of research and pedagogy in the academy. Such efforts have frequently been located in interdisciplinary and transnational collaborations, and in recent years have seen a particular emphasis on collaborations across the terrains of scholarship, activism and art as one key component of re-making more just, equal and ethical practices in higher education (for example, Boonzaier and Van Niekerk, 2019; Braidotti, Bozalek, Shefer and Zembylas, 2018; Shefer, Hearn, Ratele and Boonzaier, 2018). This paper is located within this context of a proliferation of experimentation and creativity in the South African context of public and institutionalised education, with a particular focus on scholarship that is directed at gender and sexual justice. While specifically drawing on local experiences in South Africa, I hope to contribute to the larger international dialogue that is concerned with the critique of dominant global and local research that disturbs (post)colonial and current neoliberal capitalist, extractive, and controlling logics.

The paper thus draws on South African experiences and contexts to employ transnational intersectional arguments about how our work remains underpinned and continually reproduces existing hegemonies of intersectional gender inequalities and divides that are located within the colonial and patriarchal orthodoxies of scholarly epistemology, ontology and methodology. Arguing for the imperative of collaborations which challenge the Cartesian divide and associated binarisms inherent in the hegemonic institutionalised practices of patriarchal and colonial scholarship, the article then shares some of the recent examples of work in and outside the academy which can arguably contribute to rethinking feminist, queer and decolonial scholarship on sexualities and gender in general. Located in South Africa, the critiques raised are entangled within global power relations as will be illustrated, and raise issues that are central to a larger, collective decolonial intersectional feminist project that attempts to resist repeating the violences of normative research practices.

\section{CONTEXTUALISING RESEARCH ON YOUNG SEXUALITIES IN SOUTH AFRICAN CONTEXT}

Research on young sexualities in South Africa, as in many global Southern contexts, has over the last few decades proliferated within the context of the international emphases on HIV and gender-based violence. Much of this research, apparently directed at well-meaning global justice and public health goals, has tended to be located within a particular global politics and existing inequalities, often uncritically implicated in problematic political and ideological impact, both within the methodologies employed and in how such research is taken up in the public imaginary and policy and practice. Arguably, the bulk of this research and the policies and practices it fuels, has resulted in unintended consequences and practices that have often been implicated in the normative binarisms and the consequent violences it has intended to challenge. I take up these problematic consequences to argue that the effect of such research is largely a result of the hegemonic ontologies and epistemologies that underpin dominant research practices. I attempt to illustrate also how transnational (and transethnic/class/raced within particular nation-states) practices of research, and the politics of research and global relations of power and privilege that they are located in, are deeply co-implicated. I argue that it is not only a lack of rigorous attention and reflexivity but importantly also the neglect of careful and caring relational ontologies (for example, Tronto, 1993, 2013; Barad, 2007), that undermines any efforts to achieve an ethical, just, and non-representational transnational intersectional feminist research praxis.

\section{GLOBAL SURVEILLANCE: NORTHERN INNOCENCE, PRIVILEGE AND PATRONAGE}

Since the early 1990s, as South Africa has emerged out of apartheid, culminating in the new democracy of 1994, HIV as a global and local challenge became a national imperative together with the project of building a democratic state. Consequently, a large amount of international focus and funds were directed at southern Africa and other global southern contexts. In South Africa, the wave of funding and invitations for collaborative research was not unwelcomed, especially in the aftermath of the apartheid era isolation. As a consequence, a wide range of research was initiated that focused on sexual practices in South Africa, primarily through the lens of HIV and gender-based 
violence (Vetten, 2018). Given that the epidemic was identified at this point as primarily heterosexual with its highest rates of infection among young people, much of the emphasis was on young people in poor communities and other 'risk groups' such as sex workers and migrant labourers (see for examples, Campbell, 2000; Dunkle, et al., 2007; Varga, 1997). A wide range of research projects, often fully or part- funded from North American or European money, were initiated by northern scholars, frequently drawing on the labour of local South African scholars and fieldworkers.

A number of key problematics are evident within this form of transnational collaboration. For one, it repeats a colonial model of existing privilege, power and resources being mobilised, underpinned by, and resulting in the promotion and reproduction of this very inequality. Thus, the moment of a northern scholar engaging in southern research can represent and reinsert northern privilege and power, building up and re-reifying privileged geopolitical knowledges at both an individual career level and also at a more symbolic level, when considering whose knowledge counts. While it can be argued that some South African scholars have benefitted by this focus and the influx of foreign funding to support such research, many northern scholars have also enhanced their careers through the representation of southern knowledge, reproducing a colonial model of the global south as 'fieldwork' and the global north as 'academic authority'.

Arguably, a form of global surveillance is also enmeshed in such scholarship and its subsequent implementation in policy and practice. Much of the scholarship was and continues to be located in the colonial era habits of extraction that speak to a regulation of the majority by those locating spaces of power and privilege, resulting in the deployment of authoritative knowledge to bolster regulatory and policing frameworks in South Africa. Such research has therefore been deployed in the service of the reproduction of global northern, western privileging, superiority and 'innocence' (Wekker, 2016). In this light it becomes evident that South African research on young people's sexualities bolsters a transnational global 'civilising' project characterised by (post)colonial exploitative relations between resourced and subjugated parts of the world. The intense focus on poor, Black and young South Africans and the knee-jerk association of these subjects with violence and patriarchy, fuels a narrative in which sexual violence, patriarchy and heteronormativity are seemingly exported out of the 'civilised', 'gender just' countries; this is what Grewal (2013) calls 'outsourcing' patriarchy, transposing it to those historically already subjugated and othered. Such discursive practices in the global and local imaginary is symbolic fodder for racist, colonial tropes of African sexualities that have also been unpacked in the analyses of local and global responses to HIV/AIDS and African sexualities in general (for example, Jungar and Oinas, 2004; Lewis, 2011; Patton, 1997). Further, the international concerns related to homophobic violence and 'hate crimes', that have also been prominent in sociological research, and the public and popular gaze on South Africa, are threaded through with homonationalist (Puar, 2007), and femonationalist (Farris, 2017) discourses. This interrogative surveillance similarly extends the 'civilised' and authoritative position of white, western, northern societies (for examples, Shefer, Hearn and Ratele, 2015; Jungar and Peltonen, 2015). Critical feminist postcolonial scholars have illustrated how such dynamics operate also within global northern countries whose scopophilia is redirected to the migrants, ethnic minorities and the poor and marginal within their own 'Dark Continent' - versus the hegemonic culture (for examples, Farahani and Thapar-Björkert, 2019; Jungar and Peltonen, 2016; Keskinen, 2009, 2012, 2014; Munt, 2007; Peltonen and Jungar, 2018). Thus, research on gender inequality and violence, as with popular and public representations of this, may be drawn on to bolster notions of global northern, western and white civility, advancement and supremacy, while 'othering' patriarchy and gender violences to those nations and communities already in subjugated geopolitical and ideological locations. HIV and the surveillance of sexualities in global Southern contexts has thus bolstered the colonial 'othering' and denigrating tropes of Black bodies and sexualities, indeed conflating HIV, gender and sexual injustice, and violence and illness with Black bodies (Flint and Hewitt, 2015; Settler and Engh, 2015).

At a global level, such research has fuelled the global imaginary of African violence, patriarchy and homophobia whilst casting those in more privileged nation-states as the civilising benefactors who face no troubles or injustices of their own, but are generously directing their efforts at the troubled 'others' who do face these problems. While clearly much of this emphasis is well-meaning, it also speaks to what Joan Tronto (1993; 2013) has called 'privileged irresponsibility' in which those in privileged, majority or dominant (geo)political positions fail to acknowledge their own exercise of power, thus maintaining their taken for granted positions of privilege, even when supposedly engaging in practices of care, such as researching towards gender justice. In the same way as Tronto argues that the burden of care globally falls on those who locally and globally subjugated at political, material and ideological levels, so too in the research terrain, in which privileged researchers engage a 'pass out', by not acknowledging how the 'troubles' of the global south are entangled with the privileges of the global north. Similarly, the individual careers of those in privileged positions are shaped by a 'privileged irresponsibility' which can be built into our very practices of scholarship. So, those in privileged positions, receive a 'pass out' of responsibility, rationalising their privilege through the narrative that those in less privileged positions will benefit by default from their position of privilege, using similar logic to the 'trickle down' theory of capitalism. Tronto (2013) elaborates how this privileged 
irresponsibility can allow those already benefiting from their privileged geolocation in unequal power relations, whether locally or globally, to remain ignorant of their own role in maintaining and reproducing systems of inequality. Further, those "who are privileged will continue to rationalise their position by maintaining that everybody is benefiting from it; wives benefit from their husband's being the primary breadwinners, domestic workers benefit from receiving a salary, no matter how paltry it is and so on' (Zembylas, Bozalek and Shefer, 2015: p. 207).

Researchers, always already privileged by their geopolitical, or class, or raced, or gendered location, can rationalise their work through a narrative that frequently reinforces the very othering they hope to challenge. This is of course not a new argument; now over 25 years ago Spivak's (1994: 93) ground-breaking work in which her famous remark about 'white men saving brown women from brown men' being key to colonial power dynamics, remains salient in the nuances of contemporary research conducted at transnational and transcultural local levels directed at HIV and young people's sexualities. In particular, these continued relations of patronage, that Tronto argues are a key component of privileged irresponsibility, mask the unequal power and continued violent appropriations of the lives and resources of peoples and parts of the world that remain subjugated and denigrated. Such practices of othering and denigration of certain parts and peoples of the world and certain are seldom interrogated, especially as they are repeated in scholarship that attempts to make a difference. An ethics of relationality, which acknowledges the entanglements of peoples and places, the entanglements of the privileges of some and the subjugation and marginalisation of others, is deeply lacking in dominant practices of research which remain oblivious to the damages they do and the symbolic (and actual, in some cases) violence that is set in motion.

\section{THE REPRODUCTION OF RACED, CLASSED HETERONORMATIVITY AND NORMATIVE MORALITIES}

A key concern in the research which reflects the lack of a critical feminist engagement in relation to sexualities research, is the realisation of the ways in which mainstream research on gender and sexuality in South Africa has served to reinstate stereotypic gender and sexual binaries. The reproduction of such normative discourses is also entangled within transnational and local raced and classed othering practices. Researchers have illustrated the way in which intersectional gender binarisms are reflected in the literature and the policies and practices which they serve, so that femininity, in particular poor, black, African young femininity is constructed as always vulnerable and violable (Boonzaier, 2017; Boonzaier and Kessi, 2018; Shefer, 2016, 2018a) and masculinity, particularly poor, black, African, young masculinity as inherently predatory and violating (Anderson, 2010; Bhana and Pattman, 2009; Pattman, 2007; Ratele, 2014).

For many local feminist scholars and activists, the imperative to address HIV was viewed as a potentially positive momentum intended to bring the feminist critique of heterosexuality to a more mainstream public forum. Thus, the widespread acknowledgement that the intersectional gendered dynamic of HIV infection of South Africa, identified as primarily heterosexual in these contexts, had to be key to both prevention and mitigation efforts, and was viewed as an opportunity to challenge normative gender and sexual practices and the violences that these engender. It has however becoming increasingly evident that, on the contrary, such research may be contributing to re-entrenching dominant discourses around gender and sexuality, deployed rather towards the preservation of binarisms of gender and heteronormativity within public terrains, such as sexuality education at school or in public advocacy directed at challenging HIV and/or gender inequalities (see for example, Shefer, 2016; Bhana, 2016). Research on young people's sexualities, and related policy and practice has tended to not only assume, but in many cases actively reinforce gender binarisms, and heteronormative gender performances in sexual intimacies. It has been widely argued that international research, particularly that based on the experiences of global southern countries, has tended to set up a deterministic picture of passive, submissive femininity vulnerable to an equally stereotyped hypersexual, macho masculinity (for examples, Bakare-Yusuf, 2003; Tamale, 2011). A growing body of work in local South African contexts has similarly raised such concerns about current South African research on young sexualities (for examples, Bhana and Anderson, 2013; Boonzaier and Kessi, 2018; Shefer, 2016).

Enmeshed in these reiterations of gender binarisms embedded in such research and its related practices, is the presentation of women as asexual victims to male hypersexual desires. African feminist researchers, such as McFadden (1992; 2003), have pointed out how HIV/AIDS responses in Africa have served to constrain further the spaces for women's sexual agency and a positive discourse on women's desire and pleasure. Rather, a punitive voice on young people's sexuality has been further entrenched through HIV prevention methods particularly evident in current sexuality education at school, where a gender binary and heteronormative approach to the teaching of HIV/AIDS and sexuality in general has been well documented (Macleod, 2009; Ngabaza and Shefer, 2019; Shefer, Macleod and Baxen, 2015; Bhana, Crewe and Aggleton, 2019). While sexuality education has been promoted as a way of challenging gender and sexual injustice in democratic South Africa, research has shown normative gender and sexual practices are reinscribed in the curriculum (Francis, 2017; Bhana, 2016; Bhana, Crewe 


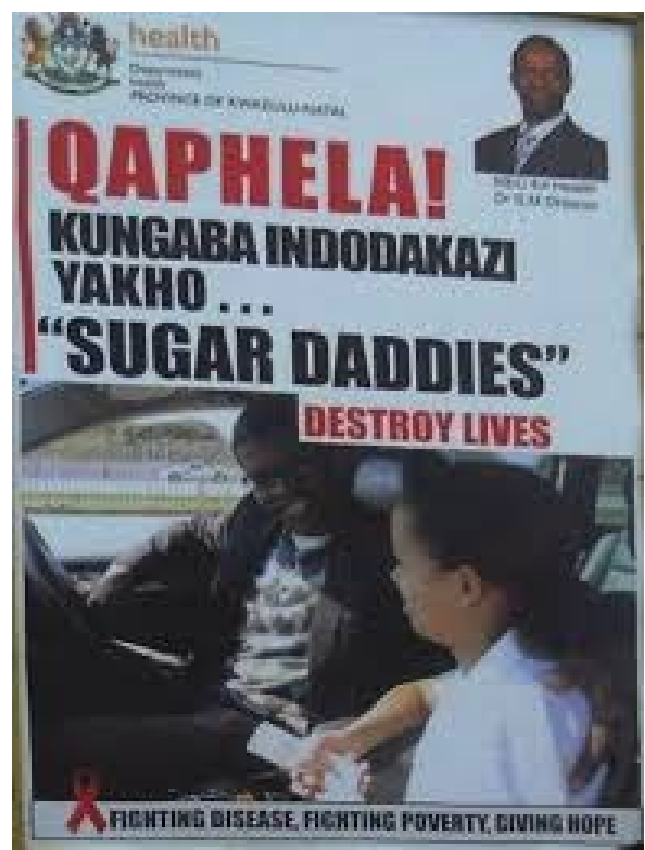

Figure 1. An example of raced and gendered stereotypes in HIV public education, Photo credit: unknown.

and Aggleton, 2019). Similarly, a growing body of research on sexuality education in South African schools, has increasingly illuminated the way in which HIV and GBV have been deployed towards governmentality over young people with respect gender, sexuality and dominant moralities (arguably shaped by northern, western, middle class framings) (for examples, Bhana, Crewe and Aggleton, 2019; Shefer, Macleod and Baxen, 2015). The reproduction and rationalisation of gender binarisms are shown to be reinforced through the dominant narrative of danger, disease and damage, in which young women in particular are set up as solely responsible for their own and their male partners' well-being (Macleod, Moodley and Saville-Young, 2015; Ngabaza, Shefer and Macleod, 2016), and for ensuring the performance of 'respectable femininity' (Van Wyk, 2015).

Notwithstanding the critique of the stereotypic picture of women as victims, the opposite research inclination is equally a problem. Feminist scholars have interrogated the attempts at flagging women as agentic, no matter their material and discursive subjugations; this binarism of agency versus victimhood continues to repeat transnational dynamics of patronage and euro-centricity, and dominant group privilege (Campbell and Mannell, 2016; Hemmings and Kabesh, 2013; Mahmood, 2001). Jungar and Oinas (2011: 255), unpack very carefully how both the impetus to assert women's agency or frame them as victims, similarly re-inscribes the privilege and authority of the researcher who has the power to name.

Heteronormativity and normative heterosexual family moralities have also insidiously driven key projects within contemporary public health research and educational interventions which are directed at young people. Much of the research and practice directed at young people has been shown to be underpinned by and focused on reanimating heterosexual normativity. For example, research tends to focus on heterosexual gender binary practices without explicitly acknowledging this, thus erasing diversity in sexual and gender desires and practices. The dominance of heteronormative and homophobic discourse and practices in school and higher educational contexts has been documented by local researchers (Francis, 2017; Bhana, 2014; Msibi, 2012). Such discourses seem everpresent in reports on how HIV and sexuality education are 'taught', threading in and through the assumption of heteronormativity, and idealised through the representation of heterosexual coupling and normative nuclear family formation as being the only imaginable sexual and intimacy outcome for young people.

As mentioned, gender stereotypes in the literature and their concomitant public effects are also typically enmeshed within racist and classist discourses, which gesture too to further challenges for transnational feminist projects. A popular media campaign, as evidenced in Figure $1^{1}$, cautioned against transactional sex. Diverse versions of this message were posted in public spaces on large billboards for some years in the 2000s as part of the larger HIV/AIDS mass educational campaign. These provide an example of the way in which dominant discourses on gender, race, class and age are entangled with such educational interventions (see Brouard and Crewe, 2013; Shefer and Strebel, 2013).

\footnotetext{
${ }^{1}$ A reproduction of one example of these billboards is available online at http://www.kznhealth.gov.za/sugardaddy.htm. (Accessed 29 January 2021). For further examples of these images see http://www.hsrc.ac.za/uploads/pageContent/4705/ Shefer.pdf for further examples, (Accessed 29 January 2021).
} 
This government poster campaign and the general publicity around transactional sexual relationships warn young poor women against relationships with older, better-resourced men through images that reproduce intersectional raced and gendered stereotypes. Notably, billboards were only located in poor Black communities and portrayed a young, poor, Black woman in a markedly submissive, vulnerable pose in relation to a well-dressed, macho, predatory, older Black man. Notwithstanding the critical research towards a more nuanced picture of materiality and sexual intimacy in South African contexts (Hunter, 2010; Bhana and Pattman, 2009; LeclercMadlala, 2004), such public images reproduce stereotypical representations of femininity and female sexuality as submissive, passive and lacking in agency and of young (and older) men as inevitable perpetrators. Further, such images reiterate racist and classist tropes, and in particular the negative constructions of poor, Black men, assumed to be inherently violent and abusive, both in the research and in public and educational contexts (Bhana and Pattman, 2009; Pattman, 2007; Ratele, 2014).

One crude example of the impact of gender scholarship on this racist and sexist public imaginary was evident in the comments made following the publication of a research project in South Africa that found that one in three men admitted to rape (see Jewkes et al., 2010). Responses on a blog discussion linked to an international posting of this research project (Tay, 2010) illustrate the manipulative way in which the research findings were deployed towards racist and global 'othering' ends, both demonising Black South African men while also ridiculing feminist researchers:

You can always tell feminist statistics — they paint 'men' with a broad brush, but somehow never manage to get around to analyzing the racial makeup of the 'men' in question. One would think that would be an important piece of information for women who wanted to avoid being victimized, but apparently not.

Yeah, I got that too. Feminist statistics are often cooked to 'prove' pre-assumed conclusions. You wonder how many feminists supported the anti-apartheid movement. And now they can not face one of the outcomes of black majority rule. Perhaps they also can not face up to the reality that the best defense of women is with a white male patriarchal system. Like apartheid ${ }^{2}$.

\section{RETHINKING RESEARCH DIRECTED AT YOUNG PEOPLE'S SEXUALITIES}

My project in this article was to unpack some of the challenges of contemporary research that is focused upon young sexual practices in South African contexts, and link this to a larger concern about challenging normative colonial and masculinist scholarly practices within the global practices of knowledge. I have attempted to expose some of the key problematic political effects of current emphases in research, in particular paying attention to how scholarship and the practices they inform have tended to reinstate and bolster gender binarisms, and be framed by racist, classist and ageist discourses, as well as to identify themes of geopolitical privilege in dominant nation-states and consequently identify patterns of global white, northern and western superiority in general. I have shown the troubling nature of transnational research on sexualities that may be implicated in the reproduction and reiteration of these very discourses and material inequalities that they aim to address.

Key to disrupting the problematic dynamics of current waves of research practice, such as that which takes place in schools and reappears in the public imaginary, demands of feminists a deeper engagement with reconceptualising academic 'business as usual'. I argue that this means developing a more cautious reflexivity about the politics of how we do our scholarship, and how it subsequently might or does get taken up in the public imaginary. This practice of conscious and cautious thoughtfulness means us going beyond reflexivity to engage with an ethics of care and relationality, so as to foreground, at all times, our entanglements with each other, across and beyond nation-states and indeed beyond the human. In our research this means seeking ever-inventive ways to disrupt the authority and the logic of surveillance and 'othering' that is built into the normative, colonial logics and practices of research.

In our research this would mean imagining, experimenting with and finding ways to do scholarly work that challenges the epistemic violence of the academy that scholarship on sexuality and gender has been shaped by, and motivate us instead to reflect 'on the ways in which this system can be interrupted through a self-conscious and deliberate set of pedagogies, methodologies, and tactics' (Nagar, 2013: 3). One terrain for such an interruption I

\footnotetext{
2 These comments were made anonymously by readers of this news article posted in the Los Angeles Times (https://www.amren.com/news/2010/11/more_than_1_in/. (Accessed 11 May 2011). Notably the article is still available but the comments are no longer appended. I cite from the copy of a blog that I had made at the time. While now 10 years old, this example remains salient and the political impact of research, especially given continued and recalcifying global racism, is still hugely concerning.
} 
argue, in line with Nagar and others, is the possibilities opened up through dialogue and collaborations between scholars, activists and artists. Thus, attempts to engage a collaboration across art, activism and scholarship seems a particularly fruitful avenue to pursue further, especially since such collaborations may serve to destabilise the dominant colonial, patriarchal logics of the academy in which bodies, affect and relationality are continuously denigrated and excluded in a long intellectual commitment to mind, rationality and individualism. In this respect scholars could work in dialogue with the proliferating mobilisations of alternative forms of scholarship and practice that cross and deconstruct boundaries of discipline, nation-state and mobilities.

The South African contemporary context of student and civil society activism that speaks to intersectional sexual and gender justice concerns within a decolonial project is a case in point which can offer a rich space for re-thinking feminist scholarship. As part of the student resistance to continued intersecting inequalities and exclusions which began in 2015 at South African universities, and constituted what has become known as the \#fallist movement, decolonial, feminist and queer activism has been bolstered in this country (Gouws, 2016, 2017; Shefer, 2018a; Xaba, 2017). This has also been regenerative for global activism in higher education (for example, Omarjee, 2018). There are many current moments, actions and movements that represent this taking up of intersectional gender justice struggles in novel and creative ways, and that in particular draw on performative, artistic modes of engagement (Shefer, 2018b). Such engagements offer rich resources for a critical transnational intersectional feminist scholarship on gender and sexuality, as well as providing productive, inspiring and ethical ways of challenging hegemonic epistemic violent practices within higher education. Embodied, participatory and creative modalities in our pedagogical practices in the academy will also open up spaces for reimagining bodies, affect, materiality, in the clinical, cold and civilising academy where so many of us feel unsafe, non-belonging, excluded, and violated. They may also provide everyday utopian moments (Cooper, 2014) and everyday microand macro-resistances that can open the space for alternative imaginaries of intersectional gender and sexual justice and equality.

Such forms of scholarship that embrace and model the creative entanglements of art, activism and research can also transgress the normative logics of disembodied and dis-affected/ive scholarship in which the mind and rationality dominates. Through such embodied, affective ascholarly projects and situated knowledges - which resist extractivist methods in research - the foregrounding of a relational ontology, recognition, and an ethics of care, both materially and symbolically, is made possible. Thinking with activist-performance and performative-activism in our pedagogies and research, such as the activism and art of young South Africans in contemporary South Africa, can be a powerful way of transgressing and resisting the rigid normativities and symbolic violences of the academy, and colonial and patriarchal repetitions in our scholarship. Haraway (2016: 1) invites us to not only stay with the trouble, but to actively 'make trouble, to stir up a potent response to devastating events' while also creating safe spaces 'to settle troubled waters and rebuild quiet places'. Such an argument further speaks to the value of working and thinking with activisms, performances, moments and spaces of creativity, agency and energy that can work with entangled 'troubles' and in doing so open up new imaginaries. Occasions that 'make trouble' such as the many current examples of inspiring, decolonial, feminist and queer art, performance and activism in current South Africa and further afield are rich resources in engaging 'new' tools for sexual and gender justice scholarship in transnational contexts. A critical transnational decolonial feminism that is concerned with engaging a different kind of scholarship that avoids the violences highlighted here in the area of young sexualities research has much to gain from making further collaborations with the rich archive of performative, artistic activisms in South Africa. These should not be drawn on merely as 'data' to enhance individual careers in the neoliberal capitalist economy of higher education, but should be acknowledged as powerful and leading scholarship-activisms themselves, that speak to new imaginaries of gender and sexual justice. Such new epistemologies might constitute new critical tools for a transnational, intersectional feminist scholarship.

Embedded within rethinking our scholarship through relationality and an ethics of care is the importance of dislodging habits of colonial thinking and knowledge making - that feminists are not innocent of. Acknowledging that contemporary scholarship has been directed by what Queer Theorist Eve Kosofsky Sedgwick (2003) has termed a paranoid reading which has privileged a particular kind of academic critique, frequently articulated as a masculinist engagement of seeking power, we must argue further for the importance of 'reparative readings' in rethinking of transnational feminist scholarship, in order to allow for the generation and acknowledgement of multiplicity, resistance, disruption of normative logics, and creativity. I have tried to show that much of the current research and practice has provided little space for acknowledging and/or studying resistances and counterhegemonic practices in contemporary contexts, but rather has largely reproduced problematising and pathologising speculatory lenses in which certain bodies, identities, practices and desires are under scrutiny and need to be controlled, regulated and/or erased. Sedgwick (2003) in her distinction between paranoid and reparative readings has argued that the dominance of deconstructive readings in critical scholarship may have silenced alternative readings. While Sedgwick (2003: 125) is not critical of paranoid readings, which she views as 'strong theory', she was concerned that the 'methodological centrality of suspicion to our current critical practice has involved a 
concomitant privileging of the concept of paranoia' which 'systematically disallows any explicit recourse to reparative motives, no sooner to be articulated than subject to methodological uprooting' (Sedgwick, 2003: 144). Sedgwick's call for reparative readings is not by any means a call for an abandonment of critical or paranoid theory, but rather suggests a space for an appreciation of the motive of reparation in our work. While Sedgwick (2003: 150) does acknowledge the problematic 'vocabulary for articulating any reader's reparative motive toward a text or culture' which she claims has 'long been so sappy, anesthetising, defensive, anti-intellectual that it is no wonder few critics are willing to describe their acquaintance with such motives', she also flags the value of finding ways to attend to the 'reparative motives and positionalities' which 'undertakes a different range of affects, ambitions, and risks'.

In the academy, this would entail the necessity of finding ways to challenge the epistemic violence that scholarship on young sexualities and genders has been shaped by. Working across the Cartesian divide underpinning the (post)colonial, neoliberal academy (and larger public realms) in which body and affect have been othered and erased within normative practices of pedagogy and research, this article makes a case for the opening up of the possibilities offered by working across multiple locations of knowledge making that can resist the binarisms and their repetitive privileging of rationality over emotion/affect, the mind over embodied knowledges, intellectual over art and activist insights; research over pedagogy (amongst others.) It also means forging a disruption to the normative logic of everyday scholarship that is shaped by symbolic linearity and containment, enacted through a combative, individualist project of seeking power and authority in a brutally bounded terrain, what Kamler and Thompson (2006: 29) have called 'occupied territory ... with all the imminent danger that this metaphor implies_-including possible ambushes, barbed wire fences, and unknown academics who patrol the boundaries of the already occupied territories'. Feminist scholars, notwithstanding their attempts at reflexivity, frequently repeat the very violences they seek to subvert, since we are all entangled in multiple and intersecting relations of power and privilege. I argue here for the importance of locating a critical transnational intersectional feminist project within the larger framework of an ethical, relational and reparative reconceptualisation of scholarship. It is increasingly imperative for a critical reflexivity to disturb what seems to be the inevitability of the co-option of our scholarship for oppressive and violent ends. At the same time, we need to continue working towards research and pedagogical practices that destabilise academic authority and its binary logics, and instead work with diverse knowledges that contribute to alternative and ethical imaginaries of intersectional, transnational feminist gender and sexual justice scholarship.

\section{ACKNOWLEDGEMENTS}

My appreciation to the Andrew W. Mellon Foundation funded project New imaginaries for an intersectional critical humanities project on gender and sexual justice (Grant no: G-31700714).

\section{REFERENCES}

Anderson, B. (2010). 'Coloured' boys talk: Constructing heterosexual masculinities in a working class high school context. Journal of Psychology in Africa, 20(4), 635-646. https:/ / doi.org/10.1080/14330237.2010.10820421

Bakare-Yusuf, B. (2003). Beyond determinism: The phenomenology of African female existence. Feminist Africa, 2, $8-24$.

Barad, K. (2007). Meeting the Universe Halfway: Quantum physics and the entanglement of matter and meaning. Durham: Duke University Press. https:// doi.org/10.1215/9780822388128

Bhana, D. (2014). Under Pressure: The regulation of sexualities in South African secondary schools. Johannesburg, South Africa: MaThoko's Books.

Bhana, D. (2015). Gendering the Foundation: Teaching Sexuality Amid Sexual Danger and Gender Inequalities. Perspectives in Education, 33(2), 67-79.

Bhana, D. (2016). Childhood Sexuality and AIDS Education: The price of innocence. New York, NY: Routledge. https://doi.org/10.4324/9781315723051

Bhana, D. and Anderson, B. (2013). Desire and Constraint in the Construction of South African Teenage Women's Sexualities. Sexualities, 16, 548-564. https:/ / doi.org/10.1177/1363460713487366

Bhana, D. and Pattman, R. (2009). Researching South African Youth, Gender and Sexuality Within the Context of HIV/AIDS. Development, 52(1), 68-74. https://doi.org/10.1057/dev.2008.75

Bhana, D., Crewe, M., and Aggleton, P. (2019). Sex, Sexuality and Education in South Africa. Sex Education, 19(4), 361-370. https://doi.org/10.1080/14681811.2019.1620008 
Boonzaier, F. (2017). The Life and Death of Anene Booysen: Colonial Discourse, Gender-Based Violence and Media Representations. South African Journal of Psychology 47(4), 470-481. https://doi.org/10.1177/ 0081246317737916

Boonzaier, F. and Kessi, S. (2018). Challenging Representations: Participatory Research Engagements with Young People in Postcolonial Contexts, in T. Shefer, J. Hearn, K. Ratele, and F. Boonzaier (eds) Engaging Youth in Activism, Research and Pedagogical Praxis: Transnational and intersectional perspectives on gender, sex, and race (pp. 125146). New York and London: Routledge. https:// doi.org/10.4324/9781315270470-8

Boonzaier, F. and Van Niekerk, T. (eds) (2019). Decolonial Feminist Community Psychology. Basel: Springer Nature. https://doi.org/10.1007/978-3-030-20001-5

Bozalek, V., Braidotti, R., Zembylas, M. and Shefer, T. (eds) (2018). Socially Just Pedagogies in Higher Education: Critical posthumanist and new feminist materialist perspectives. London: Bloomsbury. https://doi.org/10.5040/ 9781350032910

Brouard, P. and Crewe, M. (2013). Sweetening the Deal? Sugar Daddies, Sugar Mummies, Sugar Babies and HIV in Contemporary South Africa. Agenda, 26(4), 48-56. https://doi.org/10.1080/10130950.2012.757862

Campbell, C. (2000). Selling sex in the time of AIDS: The psycho-social context of condom use by sex workers on a Southern African mine. Social Science \& Medicine, 50, 479-494. https://doi.org/10.1016/S02779536(99)00317-2

Campbell, C. and Mannell, J. (2016) Conceptualising the Agency of Highly Marginalised Women: Intimate Partner Violence in Extreme Settings. Global Public Health, 11(1-2), 1-16. https://doi.org/10.1080/17441692.2015 .1109694

Cooper, D. (2014). Everyday Utopias: The conceptual life of promising spaces. Durham \& London: Duke University Press. https://doi.org/10.1515/9780822377153

Dunkle, K. L., Jewkes, R. K., Nduna, M., Jama, N., Levin, J., Sikweyiya, Y., and Koss, M. P. (2007). Transactional Sex with Casual and Main Partners Among Young South African Men in the Rural Eastern Cape: Prevalence, Predictors, and Associations with Gender-Based Violence. Social Science \& Medicine, 65, 1235-1248. https://doi.org/10.1016/j.socscimed.2007.04.029

Farahani, F. and Thapar-Björkert, S. (2019) Postcolonial Masculinities: Diverse, Shifting and in Flux, in L. Gottzén, U. Mellström and T. Shefer (eds), Routledge International Handbook of Masculinity Studies (pp. 92-102). London: Routledge. https://doi.org/10.4324/9781315165165-9

Farris, S. (2017). In the Name of Women's Rights: The rise of femonationalism. Durham, N.C.: Duke University Press. https://doi.org/10.1215/9780822372929

Flint, A. and Hewitt, V. (2015). Colonial Tropes and HIV/AIDs in Africa: Sex, Disease and Race. Commonwealth and Comparative Politics, 53(3), 294-314. https:/ / doi.org/10.1080/14662043.2015.1051284

Francis, D. (2017). Troubling the Teaching and Learning of Gender and Sexuality Diversity in South African Education. New York: Palgrave Macmillan. https://doi.org/10.1057/978-1-137-53027-1

Gouws, A. (2016). Young Women in the 'Decolonizing Project' in South Africa: From Subaltern to Intersectional Feminism. Paper presented at the Nordic Africa Days Conference 2016, Uppsala, 23-25 September.

Gouws, A. (2017). Feminist Intersectionality and the Matrix of Domination in South Africa. Agenda, 31(1), 19-27. https://doi.org/10.1080/10130950.2017.1338871

Grewal, I. (2013). Outsourcing Patriarchy: Feminist Encounters, Transnational Mediations and the Crime of 'Honour Killings'. International Feminist Journal of Politics, 15(1), 1-19. https://doi.org/10.1080/ 14616742.2012.755352

Haraway D. J. (2016). Staying with the Trouble: Making kin in the Chthulucene. Durham: Duke University Press. https://doi.org/10.1515/9780822373780

Hearn, J. (2018). Personally Rememorizing Young People Differently: What Might Critical Adult Studies (Paradoxically) Have to do with Researching, and Engaging with, Young People, in T. Shefer, J. Hearn, K. Ratele, and F. Boonzaier, (eds), Engaging Youth in Activism, Research and Pedagogical Praxis: Transnational and intersectional perspectives on gender, sex, and race. New York: Routledge. https://doi.org/10.4324/9781315270470-3

Hearn, J., Ratele, K. and Shefer, T. (eds.) (2015). Special Issue: Men, Masculinities and Young People: North-South Dialogues. NORMA: International Journal for Masculinity Studies, 10(2).

Hemmings, C. and Kabesh, A. T. (2013). The Feminist Subject of Agency: Recognition and Affect in Encounters with 'the Other', in S. Madhok, A. Phillips, and K. Wilson (eds), Gender, Agency, and Coercion (pp. 29-46). London, England: Palgrave Macmillan. https://doi.org/10.1057/9781137295613_3

Hunter, M. (2010). Love in the time of AIDS: Inequality, gender and rights in South Africa.

Hussen, T. S. (2018). ICTs, Social Media and Feminist Activism: \#RapeMustFall, \#NakedProtest, and \#RUReferenceList Movement in South Africa, in T. Shefer, J. Hearn, K. Ratele and F. Boonzaier (eds), Engaging Youth in Activism, Research and Pedagogical Praxis: Transnational and intersectional perspectives on gender, sex, and race (pp. 199-214). New York and London: Routledge. 
Ishengoma, J. M. (2016). North-South Research Collaborations and Their Impact on Capacity Building: A Southern Perspective, in T. Halvorsen and J. Nossum (eds), North-South Knowledge Networks: Towards equitable collaboration between academics, donors and universities (pp. 149-186). Cape Town, South Africa: African Minds.

Jewkes, R. K., Dunkle, K., Nduna, M. and Shai, N. (2010). Intimate Partner Violence, Relationship Power Inequality, and Incidence of HIV Infection in Young Women in South Africa: A Cohort Study. Lancet, 376(9734), 41-48. https://doi.org/10.1016/S0140-6736(10)60548-X

Jungar, K. and Oinas, E. (2011). Beyond Agency and Victimisation: Re-reading HIV and AIDS in African Contexts. Social Dynamics, 37(2), 248-262. https:// doi.org/10.1080/02533952.2011.603192

Jungar, K. and Peltonen, S. (2015). 'Saving Muslim Queer Women from Muslim Hetero-Patriarchy' In LGBTI. Savior Narratives in Youth Work in Finland. NORMA, 10(2), 136-149. https://doi.org/10.1080/ 18902138.2015.1050862

Jungar, K. and Peltonen, S. (2016). Acts of Homonationalism: Mapping Africa in the Swedish Media. Sexualities, 20(5-6), 715-736. https://doi.org/10.1177/1363460716645806

Kamler, B. and Thompson, S. (2006). Helping Doctoral Students Write: Pedagogies for supervision. London: Routledge. https://doi.org/10.4324/9780203969816

Keskinen, S. (2009). Honour-Related Violence and Nordic Nation-Building, in S. Keskinen, S. Tuori, S. Irni, and D. Mulinari (eds), Complying with Colonialism: Gender, race and ethnicity in the Nordic region (pp. 257-272). Farnham, UK: Ashgate.

Keskinen, S. (2012). Limits to Speech? The Racialised Politics of Gendered Violence in Denmark and Finland. Journal of Intercultural Studies, 33(3), 261-274. https:// doi.org/10.1080/07256868.2012.673470

Keskinen, S. (2014). Re-Constructing the Peaceful Nation. Negotiating Meanings of Whiteness, Immigration and Islam in Media and Politics After a Shopping Mall Shooting. Social Identities: Journal for the Study of Race, Nation and Culture, 20(6), 471-485. https:// doi.org/10.1080/13504630.2015.1004828

Kessi, S. and Boonzaier, F. (2015). All \#Rhodes Lead to Transformation. Mail \& Guardian Online, 28/05/2015. Available at http://mg.co.za/article/2015-05-21-all-rhodes-lead-to-enlightenment. (Accessed 7 February 2021).

Kruger, L., Shefer, T., and Oakes, A. (2015). 'I Could Have Done Everything and Why Not?': Young Women's Complex Constructions of Sexual Agency in the Context of Sexualities Education in Life Orientation in South African schools. Perspectives in Education, 33(2), 30-43.

Leclerc-Madlala, S. (2004). Transactional Sex and the Pursuit of Modernity. Social Dynamics, 29(2), 1-21. https://doi.org/10.1080/02533950308628681

Lewis, D. (2011). Representing African Sexualities, in S. Tamale (ed), African Sexualities: A reader (pp. 199-216). Cape Town: Pambazuka Press.

Macleod, C. (2009). Danger and Disease in Sex Education: The Saturation of 'Adolescence' with Colonialist Assumptions. Journal of Health Management, 11(2), 375-389. https:/ / doi.org/10.1177/097206340901100207

Macleod, C., Moodley, D. and Saville-Young, L. (2015). Sexual Socialisation in Life Orientation Manuals versus Popular Music: Responsibilisation versus Pleasure, Tension and Complexity. Perspectives in Education, 33(2), 90107.

Mahmood, S. (2001). Feminist Theory, Embodiment, and the Docile Agent: Some Reflections on the Egyptian Islamic Revival. Cultural Anthropology, 16(2), 202-236. https:/ / doi.org/10.1525/can.2001.16.2.202

McFadden, P. (1992). Sex, sexuality and the problems of AIDS in Africa, in R. Meena (ed) Gender in Southern Africa: conceptual and theoretical issues (pp. 157-195). Harare: SAPES.

McFadden, P. (2003). Sexual pleasure as feminist choice. Feminist Africa, 2, 50-60.

Msibi, T. (2012). 'I'm Used to It Now': Experiences of Homophobia among Queer Youth in South African Township Schools. Gender and Education, 24(5), 515-533. https:// doi.org/10.1080/09540253.2011.645021

Munt, S. R. (2007). Queer Attachments: The cultural politics of shame. London \& Burlington VT: Ashgate Publishers.

Nagar, R. (2013). Storytelling and Co-Authorship in Feminist Alliance Work: Reflections from a Journey. Gender, Place \& Culture, 20(1), 1-18. https:/ / doi.org/10.1080/0966369X.2012.731383

Ngabaza, S. and Shefer, T. (2019). Sexuality Education in South African Schools: Deconstructing the Dominant Response to Young People's Sexualities in Contemporary Schooling Contexts. Sex Education, 19(4), 422-435. https://doi.org/10.1080/14681811.2019.1602033

Ngabaza, S., Shefer, T. and Macleod, C. (2016). 'Girls Need to Behave like Girls You Know': The Complexities of Applying a Gender Justice Goal within Sexuality Education in South African Schools. Reproductive Health Matters, 24(48), 71-78. https://doi.org/10.1016/j.rhm.2016.11.007

Omarjee, N. (2018). Reimagining the Dream: Decolonising academia by putting the last first. Leiden: African Studies Centre.

Pattman, R. (2007). Researching and Working with Boys and Young Men in Southern Africa in the Context of HIV/AIDS: A Radical Approach, in T. Shefer, K. Ratele, A. Strebel, N. Shabalala, and R. Buikema (eds), From Boys to Men: Social constructions of masculinity in contemporary society (pp. 33-49). Cape Town: UCT Press. 
Patton, C. (1997). Inventing 'African AIDS’. In R. Lancaster and M. di Leonardo (eds), The Gender/Sexuality Reader: Culture, history, political economy (pp. 387-405). New York: Routledge.

Peltonen, S. and Jungar, K. (2018). The Ascendency of Whiteness: On Understanding Racialized Queerness in LGBTQI Refugee Work, in T. Shefer, J. Hearn, K. Ratele and F. Boonzaier (eds), Engaging Youth in Activism, Research and Pedagogical Praxis: Transnational and intersectional perspectives on gender, sex, and race (pp. 57-74). New York: Routledge.

Pietermaritzburg: University of KwaZulu-Natal Press.

Puar, J. (2007). Terrorist Assemblages: Homonationalism in queer times, Durham, NC: Duke University Press. https://doi.org/10.1215/9780822390442

Ratele, K. (2014). Currents Against Gender Transformation of South African Men: Relocating Marginality to the Centre of Research and Theory of Masculinities. NORMA: International Journal for Masculinity Studies, 9(1), 3044. https://doi.org/10.1080/18902138.2014.892285

Sedgwick, E. K. (2003). Touching Feeling: Affect, pedagogy, performativity. Durham \& London: Duke University Press. https:// doi.org/10.1215/9780822384786

Settler, F. and Engh, M. H. (2015). The Black Body in Colonial and Postcolonial Public Discourse in South Africa. Alternation, 14, 126-148.

Shefer, T. (2016.) Resisting the Binarism of Victim and Agent: Critical Reflections on 20 Years of Scholarship on Young Women and Heterosexual Practices in South African Contexts. Global Public Health: An International Journal for research, policy and Practice, 11(1-2), 211-223. https:// doi.org/10.1080/17441692.2015.1029959

Shefer, T. (2018a). Embodied Pedagogies: Performative Activism and Transgressive Pedagogies in the Sexual and Gender Justice Project in Higher Education in Contemporary South Africa, in V. Bozalek, R. Braidotti, T. Shefer, and M. Zembylas (eds), Socially Just Pedagogies in Higher Education: Critical posthumanist and new feminist materialist perspectives (pp. 171-188). London: Bloomsbury. https://doi.org/10.5040/9781350032910.ch-010

Shefer, T. (2018b). 'Doing Gender' on Campus: Students' Experiences of Normative Practices of Heterosex in South African Higher Educational Contexts and Some Critical Reflections on Dominant Responses, in R. Pattman, and R. Carolissen (eds), Transforming Transformation in Research and Teaching at South African Universities (pp. 271-289). Stellenbosch: SUN Press.

Shefer, T. and Strebel, A. (2013). Deconstructing the 'Sugar Daddy': A Critical Review of the Constructions of Men in Intergenerational Sexual Relationships in South Africa. AGENDA, 26(4), 57-63. https://doi.org/10.1080/10130950.2012.760837

Shefer, T., Hearn, J. and Ratele, K. (2015). North-South Dialogues: Reflecting on Working Transnationally on Young Men, Masculinities and Gender Justice. NORMA: International Journal for Masculinity Studies, 10(2), 164178. https://doi.org/10.1080/18902138.2015.1050864

Shefer, T., Hearn, J., Ratele, K. and Boonzaier, F. (eds) (2018). Engaging Youth in Activism, Research and Pedagogical Praxis: Transnational and intersectional perspectives on gender, sex, and race. New York and London: Routledge. https://doi.org/10.4324/9781315270470

Shefer, T., Macleod, C. and Baxen, J. (eds). (2015). Special Issue: Life Orientation Sexuality Education and Gendered Norms, Justice and Transformation. Perspectives in Education, 33(2).

Spivak, G. (1988), 'Can the Subaltern Speak?', in C. Nelson and L. Grossberg (eds), Marxism and the Interpretation of Culture (pp. 271-313). Urbana, IL: University of Illinois Press. https:/ / doi.org/10.1007/978-1-349-19059-1_20

Tamale, S. (2011). Researching and Theorising Sexualities in Africa, in S. Tamale (ed) African Sexualities: A reader (pp. 11-36). Cape Town: Pambazuka Press

Tay, N. (2010). More Than 1 in 3 South African Men Say They've Committed Rape, New Survey Says. Los Angeles Times, 26 November, Posted on November 30, 2010.

Tronto, J. (1993). Moral Boundaries: A political argument for an ethic of care. New York: Routledge.

Tronto, J. (2013). Caring Democracy: Markets, equality, and justice. New York: New York University Press.

Van Wyk, S. (2015). 'Its Hard to be a Girl': Adolescent Girls' Experiences of Girlhood in Three Low-Income Communities in South Africa. Unpublished PhD dissertation, University of Stellenbosch, South Africa.

Varga, C. A. (1997). The Condom Conundrum: Barriers to Condom Use Among Commercial Sex Workers in Durban, South Africa. African Journal of Reproductive Health, 1(1), 74-88. https:/ / doi.org/10.2307/3583277

Vetten, L. (2018). Preventing Rape in South Africa Since 1976. Paper presented at Wellsexuality: Youth and contemporary notions of sexuality in South Africa. WISER, University of Witwatersrand, 8-9 March.

Wekker, G. (2016). White Innocence: Paradoxes of colonialism and race. Durham and London: Duke University Press. https://doi.org/10.1515/9780822374565 
Xaba, W. (2017). Challenging Fanon: A Black Radical Feminist Perspective on Violence and the Fees Must Fall Movement, Agenda, 31(3-4), 96-104. https:/ / doi.org/10.1080/10130950.2017.1392786

Zembylas, M., Bozalek, V. and Shefer, T. (2014). Tronto's Notion of Privileged Irresponsibility and the Reconceptualisation of Care: Implications for Critical Pedagogies of Emotion in Higher Education. Gender and Education, 26(3), 200-214. https://doi.org/10.1080/09540253.2014.901718

Citation: Shefer, T. (2021). 'Troubling' Politics of Research on Young Sexual Practices in South African Contexts. Feminist Encounters: A Journal of Critical Studies in Culture and Politics, 5(1), 11. https://doi.org/10.20897/femenc/9748

Copyright (C) 2021 by Author/s and Licensed by Lectito BV, Netherlands. This is an open access article distributed under the Creative Commons Attribution License which permits unrestricted use, distribution, and reproduction in any medium, provided the original work is properly cited. 